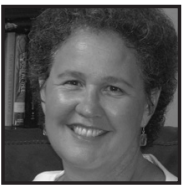

\title{
Commentary \\ Professional Learning: A Community of Practice for Great Schools
}

\author{
Linda Darling-Hammond
}

\begin{abstract}
In this interview, Linda Darling-Hammond describes the optimal way in which professional learning can be developed and implemented for teachers and school leaders. She emphasizes that teachers need to collaborate within a school and also have the opportunity to be part of a community with other schools. She explains that schools that are most successful are those where teachers, parents, and community organizations create relationships that support students inside and outside the school. As information access increases, she hopes that schools will be able to give students the skills to "learn how to learn" in order to use that information to contribute constructively to society.
\end{abstract}

From the perspective of what you've called the "blueprint for great schools" and your extensive involvement in educational policy issues, how do you envision what the best possible ways are for integrating professional learning into the lives of teachers and school leaders?

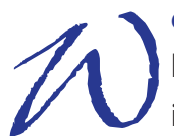

e should keep in mind at least two different pathways for professional learning. One is, of course, the work that teachers and leaders are doing in schools that's immediately in front of them: we need to structure the kind of collaboration time for planning and analysis, for coaching and developing new pedagogy and ideas, and reflecting and refining the work in the school that is needed to create a coherent and thoughtful and continuously improving school environment. 
And much of the impetus for that kind of work comes from the members of that school community themselves. We also need pathways that allow people to learn from others outside the school; that can include teachers in networks with other teachers, often subject-matter networks, schools that network with other schools, access to ongoing institutes providing learning opportunities that connect curriculum and student needs, providing knowledge that teachers can bring back into the school environment in the way that I described earlier. If we could conceptualize professional learning in those ways, rather than the idea that it's mostly someone coming in from the outside for an afternoon PowerPoint session, we would see a much greater impact from the learning opportunities that educators encounter.

\section{Can you describe an example of such an initiative that you are aware of?}

One that I can think of is the very excellent Readers / Writers Workshop run by Lucy Calkins at Teachers' College at Columbia University. They offer institutes in the summer time for a week or two where teachers come together and learn new strategies; they may develop curriculum and units and ideas to take back. They get access to coaching and a network of colleagues when they are trying things out during the school year: they can re-engage with the learning communities that they began the journey with in the summer in a variety of ways as they're trying things and refining their practices. Quite often, if the school is involved in a learning journey school-wide, teachers can connect the work to their colleagues in the school and coach each other and continuously problem solve and refine the methods and the strategies that they're implementing throughout the year. Then, if they want to, they can get another dose of a more advanced aspect of the pedagogy the following summer and so on.

Where do you feel the responsibility for excellent professional learning lies in the educational system?

It lies at almost every level, in one way. Obviously educators themselves have responsibility as professionals to continuously learn in order meet the needs of their students. It certainly lies with school site leaders who need to construct learning environments that are productive and supportive for all of the adults, not only the professionals in the building and paraprofessionals, but also often engaging parents in learning about how to support their kids and be partners in the process. Then, of course, there's the district level or the regional level creating the funding streams and the opportunities for people to learn across school sites. In some contexts, the federal 
level may also be involved in both funding and incentivizing high-quality approaches to professional learning and making sure that there are resources available for people to tap in the field for their learning.

Do you have any examples where parents have been involved in professional learning that you think are exemplary?

In New York City some years ago in 1989, the then-chancellor, Joe Fernandez, put out a call for educators, community organizations, and parents to join together to create new school designs. In the 25 years since then, New York City has almost eliminated the big factory model zoned high school and has created hundreds of small, innovative public schools, many of them in partnership between community organizations and parents and educators, who have been designing and implementing that work together. In that process, I saw many schools where parents, teachers, and principals together would engage in professional learning about aspects of the school design, even about pedagogical practices, like how will we create a strong literacy environment for all children. Parents have in some places been invited to participate in learning about various learning and teaching practices and then helping to think about the role of all of the parties in that school community in creating that kind of home and school environment.

How were they initially engaged in wanting to become part of this? How did that outreach happen?

In many cases there were schools and educators already who were working closely with parents, knew who the parent leaders were, were in communication with the community, had those relationships and ties, and they built upon them to reach further into the community with parents and community members as guides. I will also say that the places where the ties are the strongest between schools and parents and community members are often those where schools extend beyond the old routines for parent engagement, which have consisted of back-to-school night and perhaps parent-teacher conferences in the elementary school (these often disappear by secondary school in traditional schools), asking a few parents to sit on a committee, that's been our traditional model in the United States at least. These are schools where parents are involved in many more ways. The parent-teacher relationship is designed so that it doesn't only have to occur during that 10-minute parent-teacher's conference: teachers have time in their schedule put aside or paid for additionally to meet with 
parents, to do home visits, to be available after school, to engage parents in the work of creating a parent-education social calendar. Community schools are a place where a lot of this goes on.

People like Jim Comer [Dr James P. Comer], who created something called the School Development Model, designed ways that parents and staff are all working together to understand child development and then to build a lot of networks, communications, and linkages between parents, participants, and volunteers in the school and partners with teachers and the faculty themselves.

Many professionals feel that professional learning is often avoided by those who might need it most. How can this be rectified?

You have to create a context. We're moving beyond the old, isolated egg-crate classroom where teachers would be...the job was conceptualized as teachers going into that egg-crate classroom, closing their door and teaching on their own. In the new wave of preparation for teachers who are coming in, I think that's pretty much a thing of the past for those people who are newly entering. The idea that you are part of a collaborative professional community, that practice is to be shared, that that's what it means to be a professional, etc. is becoming much better planted in schools all around the globe. Certainly it's not universal, but we've moved a long way in that direction.

I think that once you can create a professional community in a school, where people are talking about practice, in and out of each other's classrooms, sharing aspects of their practice, it becomes much harder to avoid professional learning. First of all, it's all around you and it's intruding into your daily space. But second of all, as you create a set of norms and ways of being and an expectation that everyone is growing and learning, more and more people will seek out as well as graciously receive opportunities for learning. If there is a teacher who is just not oriented that way and really needs to improve aspects of his or her practice, at some point the supervisory process has to kick in and that has to become part of the expectation. I like teacher evaluation systems that involve teachers in goal setting where, together with either peers or a site leader, each teacher thinks about, "where do I want to grow, what do I want to build in my practice, how will I access the opportunities to learn about that." That puts a lot of agency in the hands of the teacher and it also creates an expectation that everyone on this ship is moving towards a continuously improving practice. 


\section{What's your vision for education in the next decade?}

Taking a U.S. perspective for a moment, I hope that over the next decade we're about to have a new Elementary and Secondary Education Act which will bring us, I hope, out of the No Child Left Behind era to a substantial extent. And I actually hope that part of what we do over the next decade is emulate some of the lessons we can learn from our neighbour to the north, from Canada, where I think the approach to improving education has been more focused on building professional capacity, developing what Michael Fullan calls "professional capital," which means collective knowledge, skill, and commitment, rather than treating teaching individualistically. I hope we will be focused on trying to meet the needs of students both inside and out of school, with a stronger health and welfare system for families and young people in addition to the investments that will be more equitable in our schools. We, of course, have a very inequitable resourcing of schools and huge increases in poverty and income inequality which add on to the challenges that many educators face.

We're making some progress in a number of states in the U.S. and I see this happening in Canada as well, towards a type of learning that acknowledges that our young people are going to have to be able to learn to learn, because the pace of knowledge production is so fast. The changeability of society, technologies, the economy is such a constant in the landscape that we need to give them the tools to be able to investigate, inquire, weigh and balance and analyze information, learn continuously from that information and environment and put that information to creative use to solve big problems. In the next decade we're going to see big changes in the way we conceptualize learning, the way we organize teaching and schooling to support it, and the kinds of outcomes we expect from it.

\section{What do you think the biggest hurdles will be?}

There are many. One big hurdle is, and this is true around the globe, the extent to which we as human beings are willing to accept and sometimes reinforce inequality, unequal opportunity to learn. That manifests differently in different societies and it manifests to different extents. There are some societies that are much more focused on and supportive of equity than others, but I think widespread inequality is a big obstacle, because our social contract won't work if only some people get access to the kind of learning that I described and the kind of learning opportunities that produce it. For any society today to survive and succeed, every member of the society needs to be very well educated. I think a failure to commit to that goal is one critical obstacle. 
There are folks in the world who see education as a marketplace, rather than a public resource and a public good, and so there are some big battles going on in various countries and around the world to privatize education, to attach fees that are only available to wealthy families, not to poor families, to differentiate the kind of opportunities that are available to create a competitive environment where schools have incentive to keep and push out kids who may have greater learning needs, rather than incentive to meet and support the greatest possible learning for all people so that they can contribute to society later. I think that's an obstacle. I think a third obstacle is the fact that everyone has gone to school and has an idea about what school should be, and often members of the public, parents, policy makers, even educators, can become tradition-bound in ways that point us towards the schools of the past, rather than the educational opportunities we need for the future. It's going to be important for people to be able to see what innovative and successful schools are doing so that they can build new images of what's possible and then develop the will to pursue that for all children.

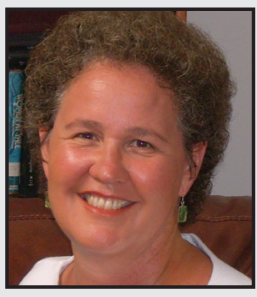

Linda Darling-Hammond is the President and CEO of the Learning Policy Institute and the Charles E. Ducommun Professor of Education Emeritus at Stanford University. She founded the Stanford Center for Opportunity Policy in Education and served as the faculty sponsor of the Stanford Teacher Education Program, which she helped to redesign. She continues to teach part-time in the Stanford Graduate School of Education. She previously served as Director of the RAND Corporation's education program and as the William F. Russell Professor of Education at Columbia University, Teachers College. Darling-Hammond is past president of the American Educational Research Association and recipient of its awards for Distinguished Contributions to Research, Lifetime Achievement, and Research-to-Policy. 